OPEN ACCESS

Citation: Maria V. Smirnova, Anna V. Korovkina (2021) Toxic and genotoxic effects of aqueous extracts of Polygonum weyrichii Fr. Schmidt on the Allium test taken as an example. Caryologia 74(2): 79-88. doi: 10.36253/caryologia-1051

Received: August 13, 2020

Accepted: July 14, 2021

Published: October 08, 2021

Copyright: (c) 2021 Maria V. Smirnova, Anna V. Korovkina. This is an open access, peer-reviewed article published by Firenze University Press (http://www.fupress.com/caryologia) and distributed under the terms of the Creative Commons Attribution License, which permits unrestricted use, distribution, and reproduction in any medium, provided the original author and source are credited.

Data Availability Statement: All relevant data are within the paper and its Supporting Information files.

Competing Interests: The Author(s) declare(s) no conflict of interest.

\section{Toxic and genotoxic effects of aqueous extracts of Polygonum weyrichii Fr. Schmidt on the Allium test taken as an example}

\author{
Maria V. Smirnova*, Anna V. Korovkina \\ Federal Research Centre "Kola Science Centre of the Russian Academy of Sciences», \\ Laboratory of medical and biological technologies 184209, Murmansk region, Apatity, \\ 14Fersman str., Russia \\ ${ }^{\star}$ Corresponding author. E-mail: zbe3do4et@mail.ru
}

\begin{abstract}
The plant Poligonum weyrichii Fr. Schmidt is a promising plant in Murmansk region because it is a valuable source of flavonoid compounds. The aim of the study is to investigate, using a sensitive and the well-established Allium test, toxic and genotoxic effects of aqueous extracts of inflorescences and leaves of the middle tier, which differ in concentration (20,50, 80 and 100\%). According to the observations, aqueous extracts of inflorescences and leaves of $P$. weyrichii of 50\%, 80\% and $100 \%$ concentration have a mitodepressive effect on the cells of the root meristem of Allium cepa L., and inhibit the root growth, causing chromosomal abnormalities. The further investigations are necessary on selection of aqueous extracts concentrations of $P$. weyrichii.
\end{abstract}

Keywords: Allium test, Polygonum weyrichii, oxidative stress, aqueous extract, flavonoids.

\section{INTRODUCTION}

The plants containing flavonoids are the promising sources for fitopreparations because of a wide spectrum of their medicinal effect. These valuable capillary strengthening, cholagogue, antiphlogistic, immunomodulatory, diuretic, antimicrobial, anticarcinogenic medications, like many others, are used in medicine. Of special interest is the antioxidant effect of flavonoids, their ability to prevent free radicals from causing much severe pathologies (Siasos et al. 2013). The oxidative stress caused by unfavourable exogenic factors, by activation of the endogenic active forms of oxygen, and by weakening of antioxidant protection of an organism, is currently considered to be an important pathogenetic link in appearance and development of many diseases (Vazhappilly et al. 2019). It can be explained by the key role of redox reactions in the cells of the organism in normal and general pathological processes. Oxidation induced by free radicals, which develops most readily in the membrane lipid phase enriched with unsaturated bonds, is the biochemical basis of the universal mechanism of the cell damage caused by different 
damaging factors. Genetic and environmental risk factors cause imbalance in the oxidants-antioxidants system, free radicals accumulation, oxidative stress development, and, as a consequence, imbalance in organ and tissues functioning. Flavonoids are a large group of polyphenols, which is synthesized by plants. A group of substances participates in many key processes of plants growth and development; however, flavonoids play the most significant role in the mechanism of non-specific plant adaptation to unfavorable environmental factors (Brunetti et al. 2013). It is possible due to their antioxidant activity.

As membrane mechanisms of damage and adaptation of plants and animals are uniform, plant ergogenic aids are successfully applied in medical practice. However, flavonoid compounds can act as prooxidants. This activity is expressed in much greater oxidation, in the formation of other radicals under redox transformations, which, in the long run, can cause a mutagenic effect. This action depends mainly on solubility, the oxidizingto-reducing agent ratio in the environment, the presence of metals with variable valence, $\mathrm{pH}$, and many other factors (Decker 2009).

Flavonoid synthesis in different organs is a common adaptive plant reaction to the effect of damaging factors of the environment.

The climatic conditions of Murmansk region are characterized by a short summer period, a short vegetation period, high humidity and extreme lighting conditions; reverse flipping between polar day and polar night (Marshall et al. 2016).

As the region is located in high latitudes, the geomagnetic field is unstable and cosmic radiation activity is high. Taking into account the data on more intensive synthesis of flavonoids by plants experiencing the effect of the extreme factors of the different nature (Yang et al. 2018), we suppose that the Arctic regions may be an important source of valuable medicinal raw materials.

The increasing incidence of diseases and a complicated course of different pathologies, which are mainly caused by oxidative stress among the residents of Murmansk region in recent years (Statistical Yearbook..., 2019) indicate the urgent need in new sources of plant flavonoids capable of increasing the nonspecific protection of the human organism from physical, chemical and biological effects.

P. weyrichii was introduced in the Kola Peninsula in 1920. This plant was often attributed to Fam. Aconogonon (Meinh.) Rchb. as A. weyrichii (F. Schmidt) H. Hara (Tsvelev 1987, 2012; Hassannejad and Ghafarbi 2017), and recently, based on the molecular-phylogenetic data, it was included into Fam. Koenigia L. (K. weyrichii
(F.Schmidt) T. M. Schust. Et Reveal) (Schuster et al. 2015). As this plant is more widely known as $P$. weyrichii in the Resource Management and Phytochemistry literature, we also use $P$. weyrichii in this study.

The representatives of this species have successfully naturalized in the local conditions and are widely distributed over the industrial area of the region. P. weyrichii is a perennial herbaceous plant, frost- and coldresistant, being distinguished for rapid growth and high productivity of the green mass. The leaves and inflorescences of $P$. weyrichii contain $3,4 \%$ to $5,6 \%$ of flavonoids by weight of dried tissue (Korovkina and Zhirov 2019), so this plant can be used as a possible source of flavonoid compounds.

The utilization of any plant for medical purposes can lead to negative consequences, so it is necessary to study the ways of producing the flavonoids compounds, their concentrations and toxicity in order to have the reliable data on its safe and efficient application in medicine.

The aim of this study is, using the Allium test, to estimate genotoxicity and toxicity of the aqueous extracts of the inflorescences and leaves of $P$. weyrichii, of different concentrations.

\section{MATERIALS AND METHODS}

\section{Plant material}

The plant material was the leaves of the middle tier and the inflorescences of naturalized $P$. weyrichii growing in the protected area of the N.A. Avrorin PolarAlpine Botanical Garden-Institute of the Kola Science Centre, the Russian Academy of Sciences (PABGI, KSC RAS) located near the town of Kirovsk, Murmansk region $\left(67^{\circ} 36^{\prime}, 33^{\circ} 40^{\prime}\right)$, Russia.

The Kirovsk site (PABGI) is located at about $340 \mathrm{~m}$ above sea level, near the Khibiny Mountains. The plant material was collected in the flowering season, on 20.07. 2019, P. weyrichii was identified by experienced biologists working at PABSI, KSC RAS.

\section{The extraction technique}

The inflorescences and the leaves of the middle tier of the $P$. weyrichii were the plant material to be used in the experiment. According to the standards of drying and storage of medicinal plants (Waterhouse, 2001), the plant material was dried, ground into powder, $1 \mathrm{~mm}$ mesh sieved, additionally dried for $3 \mathrm{~h}$ at $60^{\circ} \mathrm{C}$ to stabilize its mass. To produce the plant aqueous extracts, 
the ground plant raw materials composed of leaves of the middle tier and inflorescences, was placed into perforated infantry glasses and then into infudirkas heated before in a boiling water bath for 15 minutes, filled with distilled water of room temperature, which was used, taking into account the corresponding water saturation coefficient given in OFS "Determination of water absorption coefficient and consumption coefficient of medicinal plant raw materials", and was drawn on a boiling water bath for 15 minutes.

Then the material was cooled for 45 minutes at room temperature, strained, and distilled water was added to reach the required volume. The aqueous extracts were used to make the Allium test. To make the Allium test, it was necessary for the aqueous extracts of leaves of the middle tier and inflorescences to be watered with distilled water to reach the concentration of $20,50,80$ and $100 \mu \mathrm{g} \mathrm{ml}$. Hydrogen peroxide 1\% (Akwu et al., 2019) was used as the positive control, distilled water was used as the negative control. To produce alcoholic extracts, the material was drawn in $70 \%$ ethanol for $24 \mathrm{~h}$ at room temperature; the plant material-to-solvent ratio was $1: 10$. The alcoholic extracts were used to quantify flavonoids.

\section{Quantifying the flavonoids}

The method based on the complexation reaction of flavonoids with aluminum chloride, was applied to determine the total flavonoid content (Belikov and Shraiber, 1970). The $0.05 \mathrm{ml}$ extract was mixed with 0.1 $\mathrm{ml}$ of $2 \%$ solution of $\mathrm{AlCl} 3$ in $96 \%$ ethanol, and the volume was adjusted to $2.5 \mathrm{ml}$ with $70 \%$ ethanol. Absorbance at $415 \mathrm{~nm}$ of the analyzed solutions was measured using a KFK-3-01 "ZOMZ" spectrophotometer. The calibration curve was obtained using the solutions of routine in $70 \%$ ethanol-water mixture $(100-1000 \mu \mathrm{g} \mathrm{ml})$. The total flavonoid complex (TFC) is calculated by the formula

\section{$\mathrm{W}$ (flavonoids) $=\left(\mathrm{k}^{\star} \mathrm{A} 415^{\star} \mathrm{V} 1^{\star} \mathrm{V} 2\right) /\left(\mathrm{M}^{\star} \mathrm{V} 3^{\star} 10^{6}\right) \mathrm{mq} / \mathrm{g}$,}

where $\mathrm{k}$ - calibration coefficient, A415 - absorbance at $415 \mathrm{~nm} \mu \mathrm{g}$; V1 - extract volume, ml; V2 - dilution volume, $\mathrm{ml} ; \mathrm{V} 3$ - analyzed sample volume, $\mathrm{ml} ; \mathrm{M}$ - mass of dried plant material, g.

\section{The Allium test}

Onion (A. серa L., 2n=16, fam. Amaryllidaceae), class Kupido, was purchased in the shop. Before the experiment, the bulbs were preserved in a dark cool place for 14 days and then were selected to be of similar diameter, were examined and pilled from old scales.

The experiment was made in accordance with Fiskesjo (Fiskesjo, 1997), with the bulbs being preliminary sprouted in distilled water for $24 \mathrm{~h}$. Then 40 bulbs were selected, 5 bulbs per each concentration and per each control, with roots of $2-3 \mathrm{~mm}$ long, which were placed into test tubes filled with aqueous extracts of inflorescences and leaves of $P$. weyrichii of 20, 50, 80 and $100 \%$ concentrations. The aqueous extracts and controls were changed for new ones once a day, with the roots being cut and placed into ethanol solution (96\%) and glacial acetic acid (3:1) for $24 \mathrm{~h}$. The roots were placed into sealed test tubes, in $80 \%$ alcohol. In total, it took 96 $\mathrm{h}$ to make the experiment in darkness at room temperature, in an encrypted form.

The cytotoxic and genotoxic effects of the plant extracts were analyzed at a microscopic level using only the meristematic part of the A. cepa roots. To prepare the medications, the roots were subject to hydrolysis and simultaneous colouring in ceramic crucibles, in the aceto-orcein solution heated to a boil over the flame of a spirit lamp. Once cooled, the crucibles were left in the dye (Medvedeva et al., 2014) for 24-72 h at temperature of $4^{\circ} \mathrm{C}$.

Three roots were used per each concentration and per each control, to prepare 3 squashed medications. Calculation was made of 1000 cells, with phases and chromosome aberrations marked, with 40x and 100x amplifications (with immersion) using the "Mikromed-1 microscope, var.1-20". Simultaneously with cells calculation, the photographs were taken with the help of the TOUPCAM 2.0 camera. In total, over 52000 cells were calculated.

To assess the root growth, new bulbs were placed in aqueous extracts of inflorescences and leaves of the similar concentrations and controls for $48 \mathrm{~h}$, and the length of all the roots was measured. In total, 217 roots were measured (Fiskesjo, 1985; Wierzbicka and Antosiewicz, 1988; O'Hare et al., 1995). The mitotic index (MI) was calculated by using the following equations (Bakare et al. 2000): $\mathrm{MI}=$ the total number of dividing cells/the total cell number) $\times 100$.

\section{Statistical analysis}

Statistical analyses were done using the program Statistica 8.0 and Microsoft Excel. The differences in the mitotic rate between the experimental and control groups (the negative control) were tested applying the Mann-Whitney non-parametric test. The significance 
level was taken as $\mathrm{p} \leq 0.05$.

\section{RESULTS AND DISCUSSION}

The study presents the primary estimation which has been for the first time made over the genotoxicity of aqueous extracts of the $P$. weyrichii inflorescences and leaves because this plant contains a great amount of biologically active compounds, which means that it can be used in the development of medications and biological supplements. The flavonoid content in the inflorescences samples was equal to $5.9 \%$ of all the dried tissue $(5.9 \mathrm{mg}$ $\mathrm{ml})$, and in the leaves samples $-4.4 \%(4.4 \mathrm{mg} \mathrm{ml})$.

A 24-h experiment has revealed the root growth inhibition, root dying the colour of the solution, and root roughening in 20\%,50\% and $100 \%$ concentrations of aqueous extracts of inflorescences and 50\% and $80 \%$ concentrations of aqueous extracts of leaves. The next day, the root growth was observed in $20 \%$ concentrations of the inflorescences aqueous extracts and in 50\% and $80 \%$ concentrations of aqueous extracts of leaves, as well as sediment and slime on the bulb bottoms in $80 \%$ and $100 \%$ concentrations of aqueous extracts of inflorescences. In $96 \mathrm{~h}$, all the roots died in 100\% concentrations of aqueous extracts both of inflorescences and leaves (Fig. 2 a, b) except $20 \%$ concentration o aqueous extracts of inflorescences and $20 \%$ and $50 \%$ concentrations of aqueous extracts of leaves.

To estimate the toxicity, we measured the length of the roots because this is the indicator of the toxicity of the substances tested. This indicator is easily correlated with the microscopic data, and takes no time to be recorded (Fiskesjö 1985; Sobrero and Ronco 2004; Konuk et al. 2007).

The concentration-dependent inhibition of the root growth in the aqueous extract of inflorescences was observed after exposure in these extracts for $48 \mathrm{~h}$ (Fig. 1).

In addition, the roots bending was observed in $20 \%$ and $50 \%$ concentrations of the inflorescences extracts after a $24 \mathrm{~h}$ exposure and in $50 \%$ and $80 \%$ concentrations of the leaves extracts after a 48-h exposure (Fig. 2 c, b). According to Levan (1949), the phenomenon like this is due to the toxic effect of the substances.

Of all the mitotic disorders, the most recurrent ones were bridges in telophase and anaphase, chromatin budding in MNs, chromosomes lagging in metaphase, chromosome fragments and their sticking. Also observed were cells-ghosts with damaged chromatin or enucleated cells, cells with apoptotic bodies, giant cells and cells with damaged membranes.

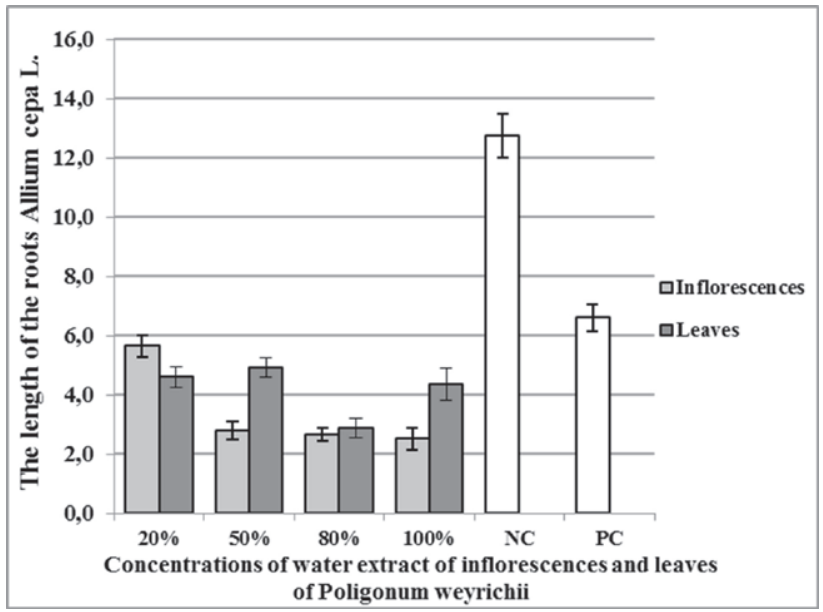

Figure 1. Dependence of the root length $(\mathrm{mm})$ of Allium cepa L. on the concentration of aqueous extracts of $P$. weyrichii (exposure 48 h). Abbreviation: NC, negative control (distilled water); PC, positive control ( $\mathrm{H} 2 \mathrm{O} 2$ 1\%). Abbreviations: $\mathrm{NC}$, the negative control (distilled water); $\mathrm{PC}$, the positive control $\left(\mathrm{H}_{2} \mathrm{O}_{2} 1 \%\right)$.

A factual, concentration-dependent, reduction in the MI compared to negative control was observed in the solutions of all the aqueous extracts of leaves and inflorescences $(p<0,05)$ (Table 1). There was also the significant reduction in the $\mathrm{MI}$ in the aqueous extract of inflorescences compared to the aqueous extract of leaves.

The aqueous extracts of plants are composed of complex mixtures of chemical substances, which effect the processes taking place in the living organisms in synergy, can be antagonists or act additively, which determines the different changes in genetic material. To assess these changes is possible by a number of tests on different objects, such as rodents (Carver et al. 1983), drosophila, cells HELA (Lu et al 2009), erythrocytes (Bhagyanathan and Thoppil 2015; Aktar et al. 2019), leukocytes (Palmieri et al. 2016), different plants, etc.

In this study we used the Allium test because it is an express-test, and is effective and sensitive when used in biological monitoring. It allows us to assess the environmental pollution, toxicity of different compounds, particles, physical factors and plant extracts (Levan 1938; Frescura et al. 2012; Frescura et al. 2013; Kuhn et al 2015; Bolsunovsky et al. 2019; Bernardes et al. 2019). The Allium test allows us to assess the cyto- and genotoxicity of the factors of different nature, not spending a lot of physical and economical resources (Teixeira et al. 2003), to avoid solving the problems connected with ethical use of plant objects; it provides with large amounts of data and the results are correlated with those obtained on cell lines (Tedesco and Laughinghouse 2012). It should be also noted that, in comparison with other plant objects 


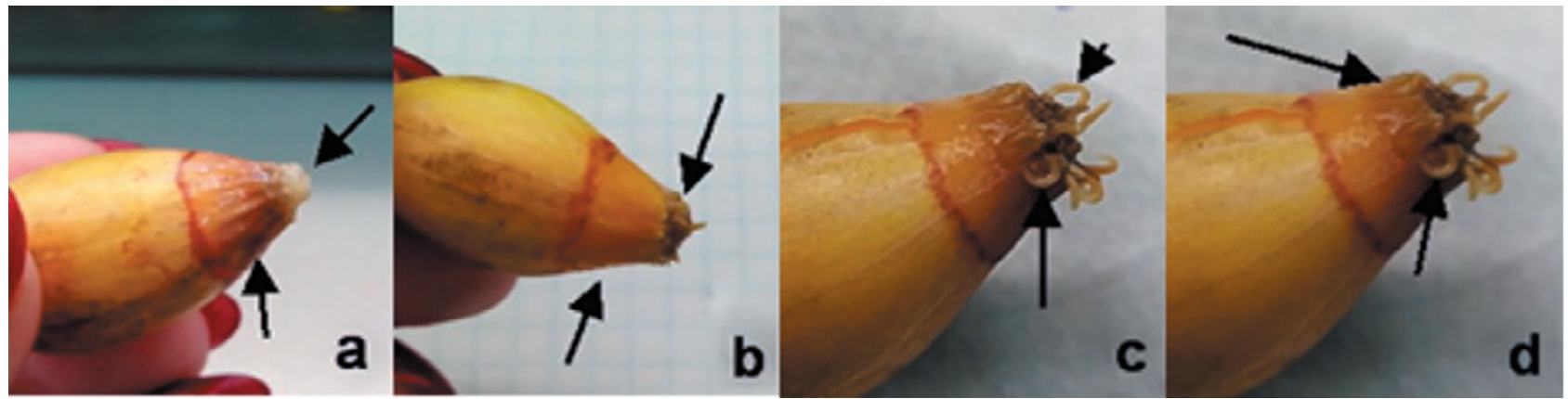

Figure 2. Death of roots in $100 \%$ aqueous extracts of inflorescences after $96 \mathrm{~h}$ (a, b) and bending of roots after exposure to aqueous extract of inflorescences and leaves 20,50 and $80 \%$ after 48 h (c, d).

Table 1. Cytological effects in the meristematic cells of roots Allium cepa.

\begin{tabular}{lcccccccccc}
\hline $\begin{array}{l}\text { Sample } \\
\text { code/ } \\
\text { indicator }\end{array}$ & MI(\%) & B & C-M & BI & DS & SC & MNs CG & CL CDM \\
\hline NC & $72.3 \pm 6.2$ & 5 & 2 & - & - & - & - & - & - & - \\
PC & $10.8 \pm 3.1$ & 2 & 1 & 56 & 12 & 10 & 2 & 182 & - & - \\
\hline inflorescences & & & & & & & & & & \\
$20 \%$ & $6.0 \pm 2.1^{\mathrm{a}}$ & 1 & - & 151 & 3 & - & 1 & - & - & 88 \\
$50 \%$ & $4.4 \pm 2.7^{\mathrm{a}}$ & 14 & 1 & 40 & 3 & 8 & 3 & - & 4 & - \\
$80 \%$ & $3.5 \pm 0.9^{\mathrm{a}}$ & & - & - & - & - & 8 & 56 & - & 96 \\
$100 \%$ & $2.0 \pm 0.4^{\mathrm{a}}$ & 6 & - & 60 & - & - & - & - & - & 253 \\
leaves & & & & & & & & & & \\
$20 \%$ & $22.1 \pm 6.6^{\mathrm{a}}$ & 10 & 1 & 162 & 1 & 8 & - & - & 1 & - \\
$50 \%$ & $5.3 \pm 1.7^{\mathrm{a}}$ & - & - & 23 & - & - & - & 20 & - & 42 \\
$80 \%$ & $5.0 \pm 1.0^{\mathrm{a}}$ & - & - & 46 & - & - & 3 & - & - & - \\
$100 \%$ & $3.3 \pm 0.9^{\mathrm{a}}$ & - & - & 23 & - & - & - & 25 & - & 28 \\
\hline
\end{tabular}

Abbreviations: NC, negative control (distilled water); PC, positive control ( $1 \%$ hydrogen peroxide $\left(\mathrm{H}_{2} \mathrm{O}_{2}\right)$; $\mathrm{MI}$ - mitotic index, $\mathrm{B}$ - bridges, C-M - C- mitosis, BI - buddings at interphase, DS destroyed spindle, SC - sticky chromosomes, MNs - micronuclei, CG - cells - ghosts, CL - 'laggard' cromosomes; CDM - cells with damaged membranes.

a Statistically different, when compared with untreated control

used in genotoxicity tests (Smirnova et al. 2012; Bonea and Bonciu 2017; Daphedar and Taranath 2018), the chromosomes and cells of $A$. cepa L. are rather great in size, which makes it easy, using primitive equipment, to count phases and mitotic disorders and assess even some changes in cells (e.g., membrane breakdown).

In testing, a number of parameters are taken into account, which allows us to get a distinct cyto- and genotoxicity pattern. These parameters are as follows: the mitotic index (MI) and a number of changes in genetic material which are classified and in scientific literature into 2 categories - clastogenic (chromatid fragments, MNs, ring chromosomes, bridges); aneugenic (chromosomes 'sticking', C-mitosis, nucleus buds, (Sharma et al. 1990, Kurás 2004) giant cells appearance)). These changes are related to disruption of the DNA molecule or chromosomes breakdown, to mitotic spindle breakdown and finalizing the cytokinesis. There is a separate category of turbagenic changes, which include laggard chromosomes, vagrants chromosomes (Bonciu et al. 2018).

The MI is an indicator of cell division, and the index reduction is related to mitodepressive effect of the substances tested (Akinboro and Bakare 2007; Sharma and Vig 2012), which was observed in the study when the concentrations of aqueous extracts of leaves and inflorescences increased. It is due to the intervention into the mitotic cycle and indicates the possible cytostatic and cytotoxic effect. The decrease in the mitotic cell activity can be related to inhibition of the DNA synthesis in the S-phase (El-Ghamery et al. 2000) or to blocking in the G2-phase of the cell cycle, which results in finalizing the entry of a cell into mitosis (Bruneri 1971; Christopher and Kapoor 1988; Sudhakar et al. 2001).

The similar effect of plant extracts has been already described as a concentration-dependent decrease in the MI in both the studies of the different, potentially medicinal and useful in industry plants, and those which are well known in medicine and production (Oyedare et al. 2009; İlbaş et al. 2012; Ping et al. 2012; Oyeyemi and Bakare 2013; Pesnya et al. 2017; De Abreu et al. 2019; Madike et al. 2019).

The flavonoid plant compounds, namely glycosides and alkaloids, as well as polyphenolic compounds possess high antioxidant activity and, in high concentrations, can induce cytotoxic effects in the test eukaryotic systems, showing the so-called prooxidant effect (Ono and Nakane 1990; Wong and McLean 1999; Lu et al. 2009; Samuel et al. 2010). The decrease in the MI, the absence of roots after 96 -h bulb incubation in the inflo- 


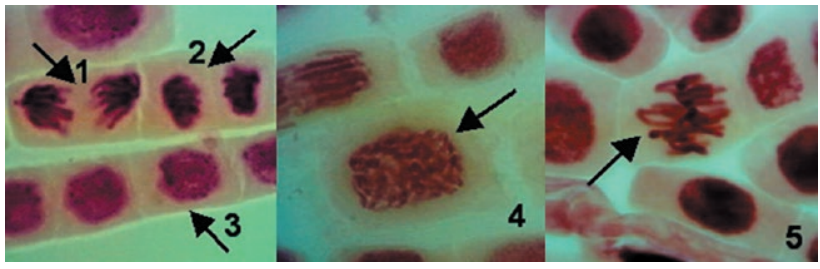

Figure 3. The mitotic phases are normal. 1) anaphase; 2) telophase; 3) interphase; 4) prophase; 5) metaphase.

rescences and leaves concentrations higher than 50\% indicate that the roots are not growing due to the inhibiting effect of the aqueous extracts of high concentrations.

The oxidation and antioxidant stress results in protein, lipids and genetic material damage (Melo et al. 2016; Zhou et al. 2016; Singh and Patra 2018; Zhou et al. 2018). Roots roughening and dying the color of the solution (dark brown hue) in aqueous extracts of leaves of $80 \%$ and $100 \%$ concentrations (the roots were longterm hydrolyzed) can be related to a high content of tanning agents, including also tannins contained in a great amount in $P$. weyrichii. In studying the plant aqueous extracts genotoxicity, the most well-known and often observed are bridges in the anaphase and telophase, lagging chromosomes, chromatin budding or breakdown in the inter-phase, MNs and C-mitosis, as a variant of breakdown or spindle inhibiting in the metaphase and disorder in microtubes functioning alongside with sticking and lagging chromosomes and fragments (Fiskesjo 1988; Pesnya et al. 2011; Prajitha and Thoppil 2016; Costalonga et al. 2017: Madić et al. 2017; Bibi et al. 2019). In this study we have observed, practically, all types of effects. The breakdowns of chromosomes in meristematic cells in the aqueous extracts of $P$. weyrichii are seen in Fig. 4, disorders are seen in Fig. 5. The mitotic phases normal in the control (distilled water), are presented in Fig.3.

The bridges in the anaphase (Fig. $4(4,11)$ can appear in the translocation process and in uneven exchange due to the presence of dicentric chromosomes, as well as due to disintegration between chromosomes and chromatids, followed by their joining (El-Ghamery et al., 2000), which results in chromosome mutations at the structural level (Devi and Thoppil, 2016).

The sticking of chromosomes occurs as a result of chromatin defect and is considered to be an irreversible process resulting in the cell death (Fig. $4(13,14)$ (Pawlowski et al. 2012).

The apoptotic cells and cells with the damaged membranes (Fig. 5) are observed in $50 \%$ and $100 \%$ concentrations of aqueous extracts of inflorescences after a

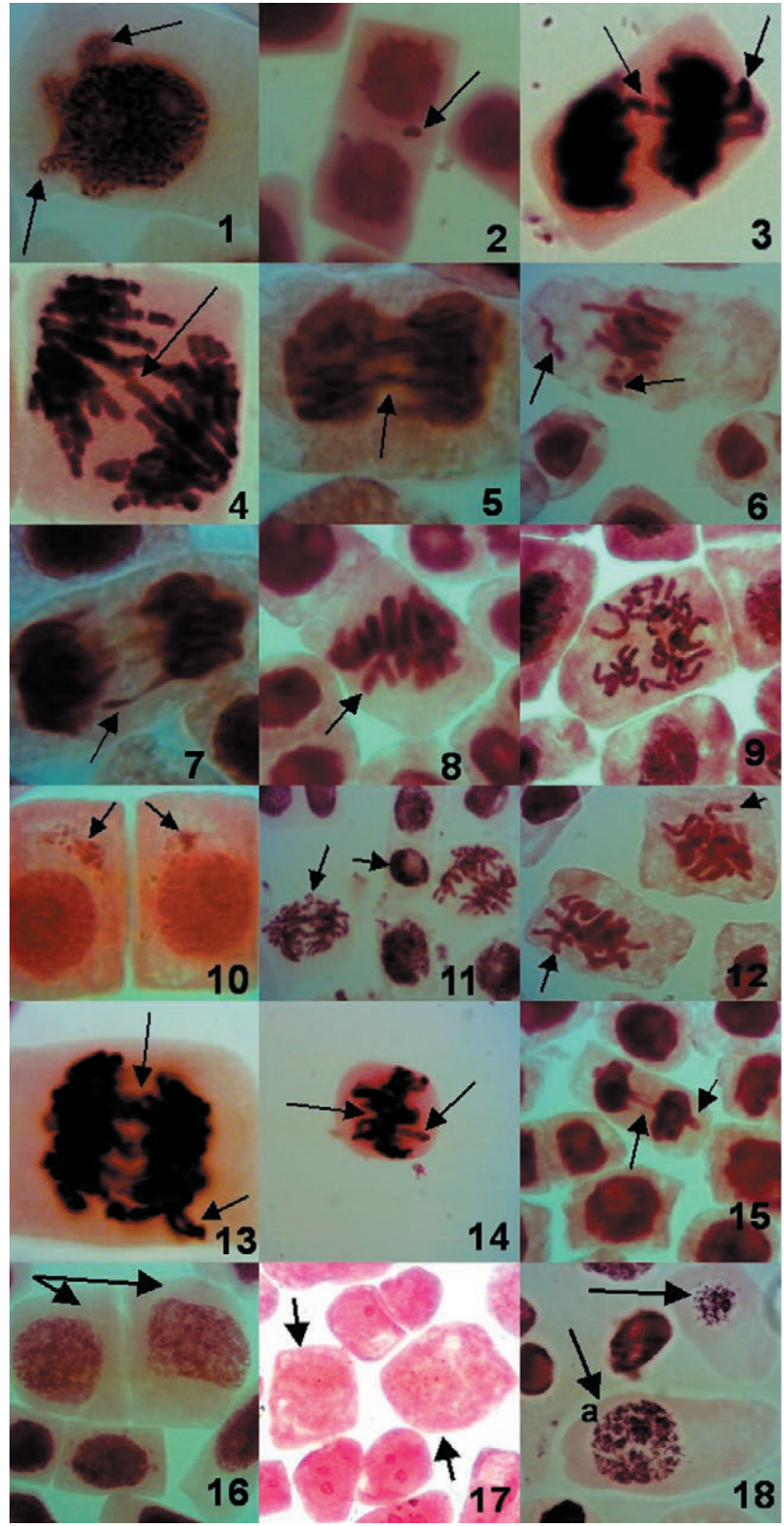

Figure 4. Chromosome and mitotic abnormalities in the roots of Allium cepa. 1) chromatin budding in the interphase; 2) micronucleus in the interphase; 3 ) chromosome lagging in the telophase; 4) a bridge in the anaphase; 5) bridges in the telophase; 6) fragments and a lagging chromosome in the metaphase; 7) chromosome lagging and their possible sticking in the telophase; 8) a lagging chromosome in the metaphase; 9) spindle destruction in the metaphase (C-mitosis); 10) chromatin fragments in the interphase; 11) chromatin destruction in the interphase, fragments and bridges in the anaphase; 12) spindle destruction in the metaphase, chromosome lagging; 13) bridges, chromosome lagging and sticking in the anaphase; 14) chromosome sticking in the metaphase and lagging. 15) a bridge in the telophase and chromatin bulgling in the nucleus which is formed; 16) giant cells; 17) nucleus-free cells (possibly due to chromatin destruction; 18) a cell-ghost and a cell with destroyed chromatin (a). 


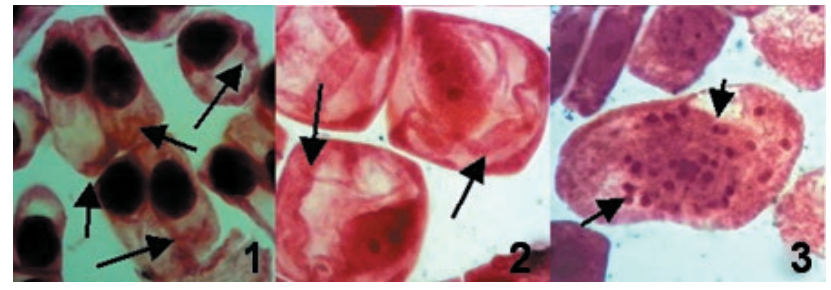

Figure 5. Various changes in the root meristematic cells of $A$. cepa. 1-2) cells with membrane damage; 3) an apoptotic cell.

24- and 18-h exposure, respectively. It can be supposed that apoptosis, as the mechanism of the programmed cell death has proven to be a reaction to a stress impact, and the damage of the cell membranes was induced by membrane ferments or by decrease in the cellulose content (Sultan and Celik 2007; 2010).

The deviations in mitosis include also elongated cells, giant cells and cells-ghosts that appear due to cytoskeleton damage in the interphase, as well as deformed nuclei and bulged chromatin, which appear in spindle and cytokines inhibiting (Mushtaq et al. 2019). For instance, giant cells and cells-ghosts (Fig. 4 (10) and Fig. 4 (18) were observed in positive control of $1 \%$ hydrogen peroxide after a $48-72 \mathrm{~h}$ exposure and in $100 \%$ concentration of the aqueous extract of leaves after a $24-\mathrm{h}$ exposure, and nucleus-free cells were observed in $50 \%$ concentration of aqueous extract of leaves after a $24-\mathrm{h}$ exposure.

The nuclear buds (Fig. 4 (1) appear due to displacement or bulging of the genetic material from aneuploid cells (Fernandes at al. 2007).

The flavonoid compounds in $P$. weyrichii, such as avicularin, hespedin, quercetin, hypricide, quercetin3-rhamnosyl, caempferol, mirecitin, epigallocatechin can explain the effects observed in the study (Adegoke et al., 1968). It is also known that some plant components, for instance, flavonoids and tanning agents, can modulate the activity of many genotoxicants (Jafferey and Rathore 2007).

In (Korovkina et al. 2020), the extract of $P$. weyrichii inflorescences is characterized by high antioxidant activity and possesses a great amount of phenol and other compounds if compared to the leaves extract, which confirms the results obtained by this study.

\section{CONCLUSION}

The study of aqueous extracts is carried out for the first time with inflorescences and leaves of $P$. weyrichii, and we believe that it contributes to understand- ing of the effect of natural extracts of potential medicinal plants on living organisms, as well as to the assessment of their toxicity and genotoxicity. The results of the study show that aqueous extracts of inflorescences and leaves of $P$. weyrichii of $50 \%, 80 \%$ and $100 \%$ concentrations have a mitodepressive effect on the cells of the root meristem of A. cepa inhibit the root growth and cause chromosome destruction. The mitodepressive effect in aqueous extracts of inflorescences was more intensive than that in aqueous extracts of leaves because the average value of the MI in aqueous extracts of leaves was 2-3 times higher. The authors suppose that these effects are due to a higher content of flavonoids and other compounds in inflorescences and due to a greater antioxidant activity, to the synergetic or antagonistic effect produced by the substances contained. This idea is to be studied further. It is necessary to go on working at selection of concentrations, qualitative and quantitative chemical analysis of the plant studied, which could serve as a source of biologically active compounds.

\section{REFERENCES}

Adegoke EA, Akinsanya A, Naqai HZ. 1968. Study of Nigerian medicinal plants I. A preliminary survey of plants alkaloids. J West AfrSci Assoc. 13:13-33.

Akinboro A, Bakare AA. 2007. Cytotoxic and genotoxic effects of aqueous extracts of five medicinal plants on Allium cepa (Linn.). J Ethnopharmacol. 112(3):470475.

Aktar A, Hassan SMH, Parvin T, Akhlas MB, Khatun F, Islam MT, Rouf R. 2019. Further phytochemical screening; non-clinical evaluation of toxic and antiinflammatory effects of crude aqueous extract of Gynura nepalensis DC. Pharmacology online.1: 136153.

Akwu NA, Naidoo Y, Singh M. 2019.Cytogenotoxic and biological evaluation of the aqueous extracts of Grewia lasiocarpa: An Allium cepa assay. South African Journal of Botany. 125: 371-380.

Bakare AA, Mosuro AA, Osibanjo O. 2000. Effect of simulated leachate on chromosomes and mitosis in roots of Allium cepa (L.). J Environ Biol. 21(3):263-271.

Belikov VV, Shrajber MS. 1970. Methods of analysis of flavonoid compounds. Farmaciya. 1: 66-73.

Bernardes PM, Andrade-Vieira LF, Aragão FB, Ferreira A, Da Silva Ferreira MF. 2019. Toxicological effects of commercial formulations of fungicides based on procymidone and iprodione in seedlings and root tip cells of Allium cepa L. Environmental Science and Pollution Research. 26:21013-21021. 
Bibi R, Christi K, Ferreira M, Cyril N. 2019. Analysis of the mitotic effect of Annona muricata leaf extracts on Allium cepa root tip cells. African Journal of Biotechnology. 18(8): 155-162.

Bhagyanathan NK, Thoppil JE. 2015. Pre-apoptotic activity of aqueous extracts of Cynanchum sarcomedium Meve\&Liede on cells of Allium cepa and human erythrocytes. Protoplasma. 253(6): 1433-1438.

Bolsunovskya A, Dementyeva D, Trofimova E, Iniatkina E, Kladkob Yu, Petrichenkovc M. 2019. Chromosomal aberrations and micronuclei induced in onion (Allium cepa L.) by gamma-radiation. Journal of Environmental Radioactivity. 207: 1-6.

Bonea D, Bonciu E. 2017. Cytogenetic effects induced by the fungicide Royal Flo to maize (Zea mays L.). Caryologia. 70(3):195-199.

Bonciu E, Firbas P, Fontanetti CS, Wusheng J, Karaismailoğlu MC, Liu D, Menicucci F, Pesnya DS, Popescu A, Romanovsky AV, Schiff S, Ślusarczyk J, de Souza CP, Srivastava A, Sutan A, Papini A. 2018. An evaluation for the standardization of the Allium cepa test as cytotoxicity and genotoxicity assay. Caryologia. 71(3): 191-209.

Bruneri. 1971. Synthesis of DNA and mitosis in relation to cell differentiation in the roots of Vicia faba and Lactuva sativa. Cytologia. 36:229-247.

Brunetti C, Di Ferdinando M, Fini A. 2013. Flavonoids as antioxidants and developmental regulators: Relative significance in plants and humans. International journal of molecular sciences. 14 (2):3540-3555.

Carver H, Carrano AV, MacGregor JT. 1983. Genetic effects of the flavonols quercetin, kaempferol, and galangin on Chinese hamster ovary cells in vitro. Elsevier Biomedical Press, Mutation Research.113: 45-60.

Christopher HB, Kapoor MB. 1988. The cytogenetic effects of sodium salicylate on the root meristem cells of Allium sativa L. Cytologia.54: 203-209.

Costalonga S, Vencioneck Dutra JC Batitucci MDCP. 2017. Mutagenic effect of three invasive species through Allium cepa bioassay. Journal of Pharmacy and Pharmacology. 5: 261-269.

Daphedar A, Taranath TC. 2018. Green synthesis of zinc nanoparticles using leaf extract of Albizia saman (Jacq.) Merr. and their effect on root meristems of Drimia indica (Roxb.) Jessop. Caryologia. 71(2):93102.

De Abreu JC, De Santana RA, Luiz Silva WS, Silva DR, Barbieri RS, Da Costa NMA. 2019. Effects cytotoxic and genotoxic of aqueous extract of fennel (Foeniculum vulgare var. vulgare mill.) Interdisciplinary Scientific Journal. 6 (1): 80-94.
Decker A. 2009. Phenolics: Prooxidants or Antioxidants? Nutrition Reviews. 55(11): 396-398.

Determination of water absorption coefficient and consumption coefficient of medicinal plant raw materials (OFS.1.4.1.0018.15 Infusions and decoctions).

Devi S, Thoppil JE. 2016. Cytotoxic studies and phytochemical analysis of Orthosiphon thymiflorus (Roth) sleesen. Int J Pharm Pharm Sci. 8(2):249-255.

El-Ghamery AA, El-Nahas AI, Mansour MM .2000. The action of atrazine herbicide as an inhibitor of cell division on chromosomes and nucleic acids content in root meristems of Allium cepa and Vicia faba. Cytologia. 65:277-287

Fiskesjö G. 1985. The Allium-test as a standart in environmental monitoring. Hereditas.102: 99-112.

Fiskesjo G. 1988. The Allium test-an alternative in environmental studies: the relative toxicity of metal ions. Mutat Res. 197:243-260.

Fiskesjö G. 1997. Allium test for screening chemicals; evaluation of cytological parameters. In: Wang W, Gorsuch JW, Hughes JS. Plants for Environmental Studies. Boca Raton, New York: CRC Lewis Publisher. 308-333.

Fernandes TCC, Mazzeo EC, Marin-Morales MA. 2007. Mechanism of micronuclei formation in polyploidizated cells of Allium cepa exposed to trifluralin herbicide, Pest. Biochem Physiol. 88:252-259.

Frescura VD, Kuhn AW, Laughinghouse HD, Nicoloso FT, Lopes SJ, Tedesco SB. 2013. Evaluation of the allelopathic, genotoxic, and antiproliferative effect of the medicinal species Psychotria brachypoda and Psychotria birotula (Rubiaceae) on the germination and cell division of Eruca sativa (Brassicaceae). Caryologia. 66(2):138-144.

Frescura VD, Laughinghouse HD, Tedesco SB. 2012. Antiproliferative effect of the tree and medicinal species Luehea divaricata on the Allium cepa cell cycle. Caryologia.65 (1):27-33.

Hassannejad S, Ghafarbi SP. 2017. A taxonomic revision of genus Polygonum L. sensulato (Polygonaceae) for Flora of Iran. Annual Res. Rev. Biol. 14 (4): 1-5.

İlbaş Aİ, Gönen U, Yilmaz S, Dadandi MY. 2012. Cytotoxicity of Aloe vera gel extracts on Allium cepa root tip cells. Turk J Bot. 36: 263-268.

Jafferey P, Rathore HS, 2007. Antigenotoxic potential of Terminalia chebula fruit (myrobalan) against cadmium in Allium Test. The Internet Journal of Toxicology. 4(1): 1-12.

Konuk M, Liman R, Ciğerci İH.2007. Determination of genotoxic effect of boron on Allium cepa root meristematic cells. Pak J Bot.39:73-79.

Korovkina AV, Zhirov VK. 2019. Environmental factors 
affecting flavonoid accumulation in plants Poligonum weyrichii growing in Murmansk region. Regulatory mechanisms in biosystems. 10(4): 553-559.

Korovkina, AV, Tsvetov NS, Nikolaev VG. 2020. Flavonoid content and antioxidant activity of extracts of Polygonum weyrichii Fr. Schmidt. IOP Conference Series: Earth and Environmental Science. 421:1-7.

Kuhn AW, Tedesco M, Laughinghouse HD, Flores FC, De Bona da Silva C, Do Canto-Dorowe TS, Tedesco SB.2015. Mutagenic and antimutagenic effects of Eugenia uniflora L. by the Allium cepa L. test. Caryologia: International journal of cytology, cytosystematics and cytogenetics. 68:25-30.

Kurás L. 2004. Characterization of protei - DNA association in vivo by chromatin immunoprecipitation. In:Dickson RC, Mendenhall MD, editors. Signal transduction protocols, methods in molecular biology. 284. Totowa: Humana Press Inc.; p. 147-162.

Levan A. 1949. The influence on chromosomes and mitosis of chemicals, as studied by the Allium test. Hereditas. 35: 325-337.

Levan A. 1938. The effect of colchicine on root mitosis in Allium. Hereditas. 24:471-486.

Lu W, Yang Y, Li Q, Liu F. 2009. Crude flavonoids from Carya cathayensis argent inhibited HeLa cells proliferation through induction of apoptosis and cell cycle arrest. Lat Am J Pharm.28:568-573.

Leme DM, Marin-Morales MA. 2009. Allium cepa test in environmental monitoring: A review on its application. Mutat Res. 682:71-81.

Madike LN, Takaidza S, Ssemakalu C, Pillay M. 2019. Genotoxicity of aqueous extracts of Tulbaghia violacea as determined through an Allium cepa assay. S Afr J Sci. 115:1-6.

Madić V, Jovanović J, Stojilković A, Jušković M, Vasiljević P. 2017. Evaluation of cytotoxicity of 'anti-diabetic' herbal preparation and five medicinal plants: an Allium cepa assay. 8(2): 151-158.

Marshall GJ, Vignols RM, Rees WG. 2016. Climate change in the Kola Peninsula, Arctic Russia, during the last 50 years from meteorological observations. Journal of climate. 29(18): 6823-6840.

Medvedeva MY, Bolsunovsky AY, Zotina TA. 2014. Cytogenetic disorders in the water plant Elodea canadensis in the zone of technogenic pollution of the river Yenisei. Siberian ecological journal. 4: 561572.

Melo PS, Arrivetti LOR, Alencar SM, Skibsted LH. 2016. Antioxidative and prooxidative effects in food lipids and synergism with a-tocopherol of açaí seed extracts and Grape rachis extracts. Food Chem. 213:440-449.
Mushtaq W, Ain Q, Siddiqui MB, Hakeem KR. 2019. Cytotoxic allelochemicals induce ultrastructural modifications in Cassia tora L. and mitotic changes in Allium cepa L.: a weed versus weed allelopathy approach. Protoplasma. 256:857-871.

O'Hare S, Atterwill CK, Totowa NJ. 1995. In vivo toxicity testing protocols. In: Methods in molecular biology, Eds. Copyr. Humana Press Inc. 43:119-127.

Ono K, Nakane H. 1990. Mechanisms of inhibition of various cellular DNA and RNA polymerases by several flavonoids. J Biochem.108:609-13.

Oyedare BM, Bakare AA, Akinboro A. 2009. Genotoxicity assessment of water extracts of Ocimum gratissimum, Morinda lucida and Citrus medica using the Allium cepa assay. Bol Latinoam Caribe Plant Med Aromat. 8(2):97 - 103.

Oyeyemi IT, Bakare AA. 2013. Genotoxic and antigenotoxic effect of aqueous extracts of Spondias mombin L., Nymphea lotus L. and Luffa cylindrica L. on Allium cepa root tip cells, Caryologia. 66 (4): 360-367.

Palmieri MJ, Andrade-Vieira LF, Cardoso TMV, De Faria EMW, Luber J, Davide LC, Marcussi S. 2016. Cytogenotoxic effects of spent pot liner (spl) and its main components on human leukocytes and meristematic cells of Allium cepa. Water Air Soil Pollut. 227 (156): 1-10.

Pawlowski A, Kaltchuk-Santos E, Zini CA, Caramao CB, Soares GLS. 2012. Essential oils of Schinuster ebinthifolius and S. molle (Anacardiaceae): mitodepressive and aneugenic inducers in onion and lettuce root meristems. South Afr J Bot. 80:96-103.

Pesnya DS, Serov DA, Vakorin SA, Prokhorova IM. 2011. A study of toxic and mitosis-modificating and mutagenic action produced by Heracleum sosnowskyi Yaroslavl' pedagogical bulletin (In Russ) (Natural sciences). 4 (3): 93-98.

Pesnya DS, Romanovsky AV, Serov DA, Poddubnaya NY. 2017. Genotoxic effects of Heracleum sosnowskyi in the Allium cepa test, Caryologia.70:1, 55-61.

Ping KY, Darah I, Yusuf UK, Yeng C, Sasidharan S.2012. Genotoxicity of Euphorbia hirta: an Allium cepa assay. Molecules. 17: 7782-7791.

Prajitha V, Thoppil JE. 2016. Genotoxic and antigenotoxic potential of the aqueous leaf extracts of Amaranthus spinosus Linn. using Allium cepa assay. South African Journal of Botany. 102: 18-25,

Samuel T, Fadlalla K, Turner T, Yehualaeshet TE. 2010. The flavonoid quercetin transiently inhibits the activity of taxol and nocodazole through interference with the cell cycle. Nutr Cancer. 62:1025-1035.

Sobrero MC, Ronco A. 2004. Ensayo de toxicidad aguda con semillas de lechuga (Lactuca sativa L.). In: Cas- 
tillo G, editor. Ensayos toxicológicos y métodos de evaluación de calidad de aguas. Estandarización, intercalibración, resultados y aplicaciones. Canadá: IDRC/IMTA; p. 71-79.

Schuster TM, Reveal JL, Bayly MJ, Kron KA. 2015. An updated molecular phylogeny of Polygonoideae (Polygonaceae): Relationships of Oxygonum, Pteroxygonum, and Rumex, and a new circumscription of Koenigia. Taxon. 64 (6): 1188-1208.

Sharma S, Panneerselvan N, Ma T-H. 1990. Genetic toxicology of pesticides in higher plant systems. Crit Rev Plant Sci. 9(5):409-442.

Sharma S, Vig AP. 2012.Genotoxicity of atrazine, avenoxan, diuron and quizalofop-P-ethyl herbicides using the Allium cepa root chromosomal aberration assay. Terrest Aquat Environ Toxicol. 6:90-95

Siasos G, Tousoulis D, Tsigkou V, Kokkou E, Oikonomou E, Vavuranakis M, Basdra EK, Papavassiliou AG, Stefanadis C. 2013. Flavonoids in atherosclerosis: an overview of their mechanisms of action. Current Medicinal Chemistry. 20(21): 2641-2660.

Singh SK, Patra A. 2018. Evaluation of phenolic composition, antioxidant, anti-inflammatory and anticancer activities of Polygonatum verticillatum (L.). J Integr Med. 16:273-282.

Smirnova MV, Petrashova DA, Belisheva NK. 2012. The efficiency of different methods used in preparations of chromosome preparators of Allium cepa L. and Vigna radiata L. In Collec.: Biodiversity and cultural cenosis in the extreme conditions. The All-Russian scientific conference with the participation of the international experts. 133-135.

Statistical Yearbook. Murmansk region. 2019. 9-40.

Sudhakar R, Ninge Gowda KN, Venu G. 2001. Mitotic abnormalities induced by silk dyeing industry effluents in the cells of Allium cepa. Cytologia. 66(3): 235-239.

Sultan AO, Celik TA. 2007. Cytotoxic and genotoxic effects of Lavandula stoechas aqueous extracts. Biologia, Bratislava. Section Cellular and Molecular Biology. 62(3): 292-296.

Sultan AO, Celik TA. 2010. Evaluation of cytotoxicity and genotoxicity of Inula viscosa leaf extracts with Allium Test. Journal of biomedicine and biotechnology. Article ID 189252: 1-8.

Tsvelev N.N. 2012. Fam. Polygonaceae Juss(besides family Rumex L.). Cyllabus of the flora of the Eastern Europe. M. St-Pb: 317-332.

Tsvelev, NN. 1987. Notes on Polygonaceae in flora in the Far East. News of the systems of highest plants. 24: 72-79.

Tedesco SB, Laughinghouse IVHD. 2012. Bioindicator of genotoxicity: the Allium cepa test. In: Srivas- tava J, editor. Environmental contamination. Croatia: InTech; p. 137-156.

Teixeira RO, Camparoto ML, Mantovani MS, Vicentini VEP. 2003. Assessment of two medicinal plants Psidium guajava L. and Achillea millefolium L., in vitro and in vivo assays. Genet Mol Biol. 26(4):551-555.

Vazhappilly CG, Ansari SA, Al-Jaleeli R, Al-Azawi AM, Ramadan WS, Menon V, Hodeify R, Siddiqui SS, Merheb M, Matar R. 2019. Role of flavonoids in thrombotic, cardiovascular, and inflammatory diseases. Inflammopharmacology. 27(5): 863-869.

Waterhouse AL. 2001. Determination of Total Phenolics. Current protocols in food analytical chemistry.

Wierzbicka M, Antosiewicz D. 1988. Allium test - some questions. Acta Societatis Botanicorum Poloniae. 57 (2): 201-215.

Wong WS, McLean AE. 1999. Effects of phenolic antioxidants and flavonoids on DN synthesis in rat liver, spleen, and testis in vitro. Toxicology. 139:243-53.

Yang L, Wen KS, Ruan X, Zhao YX, Wei F, Wang, Q. 2018. Response of plant secondary metabolites to environmental factors. Molecules, 23(4).762: 1-26.

Zhou J, Chao G, Li Y, Wu M, Zhong S, Feng Z .2016. Activation of NRF2/ARE by isosilybin alleviates A 325 -35-induced oxidative stress injury in HT-22 cells. Neuroscience Letters. 632:92-97

Zhou Y, Sun Y, Li P, Qin G, Cheng Q, Liu Y, Chen Y, Wang G .2018. Monoside antagonizes triptolideinduced hepatocyte apoptosis via the anti-oxidative stress pathway. Nan Fang Yi Ke Da XueXueBao. 38:949-955. 